\title{
REDEMPTIONS AND PARTIAL LIQUIDATIONS UNDER THE 1954 INTERNAL REVENUE CODE: THE DIVIDEND EQUIVALENCE TEST
}

The enactment of the Internal Revenue Code of 1954 was the occasion for a thorough re-examination of the statutory treatment of corporate distributions. Nevertheless, as the Code finally emerged from Congress, the law in this area contained the same basic concepts and was expressed in a statutory framework similar to that of the 1939 Code. However, new provisions were inserted and others were revised in an attempt to provide greater certainty in this complex field of taxation.

The statutory scheme defines dividends as the distribution of earnings and profits of the corporation and taxes them as ordinary income to the shareholder; on the other hand, amounts which a shareholder receives from the sale of corporate stock to a third person are treated as payment in exchange for a capital asset and are taxed as capital gain or loss. One of the most perplexing of those situations which fall in between these two extremes occurs when a shareholder surrenders some of his stock to the corporation and in return receives a distribution of money or property which may be attributable entirely to corporate earnings and profits. The difficult problem is to determine which of these transactions more closely resemble the distribution of a dividend and therefore should be taxed as ordinary income, and which are closer to a sale of corporate stock and thus should receive capital gain or loss treatment. The 1939 Code gave little guidance as to the proper classification of various situations; it merely specified that if a distribution in redemption of stock was essentially equivalent to a dividend it was to be taxed as ordinary income. As a consequence, a wide area was left to judicial and administrative discretion with resulting uncertainties to taxpayers. Although the 1954 Code continues the dividend equivalence test employed under prior law, it also contains new provisions which are intended to make the statutory indicia more definite and thus to provide greater certainty.

Since the new Code utilizes a test familiar under the prior law, the statutory scheme of the 1939 Code and the judicial pronouncements under it will first be examined. The applicable portions of the 1954 Code will then be described, and, finally, an analysis of these provisions and their relationship with the reorganization sections will be undertaken through the medium of a series of hypothetical problems.

\section{THE 1939 CODE}

\section{The Statutory Scheme}

The provisions of the 1939 Code relating to corporate distributions in redemption of stock were comparatively brief. Section 115 (a) provided 
that any distribution made by a corporation to its shareholders out of its earnings and profits of the current taxable year or accumulated since February 28,1913 , constituted a dividend, ${ }^{1}$ and therefore it was taxable as ordinary income. ${ }^{2}$ One exception to this general provision was Section 115(c) which specified that amounts distributed in partial liquidation were to be treated as in exchange for stock and thus taxed as a capital transaction. ${ }^{3}$ The term "partial liquidation" was defined in Section 115(i) as ". . a distribution by a corporation in complete cancellation or redemption of a part of its stock, or one of a series of distributions in complete cancellation or redemption of all or a part of its stock." 4 However, Section $115(\mathrm{~g})$ provided that, if the cancellation or redemption was "at such time and in such manner as to make . . . [it] essentially equivalent to the distribution of a taxable dividend," it was to be treated as a dividend. ${ }^{5}$ This section was a frequent source of litigation, because of the general language in which it was couched and because it imposed a severe limitation on the operation of Section $115(\mathrm{c})$.

\section{Judicial Interpretation of Section $115(g)^{\circ}$}

The dividend equivalence test of Section $115(\mathrm{~g})$ gave little indication to the courts of the proper standards to apply in determining which corporate distributions in redemption of stock should be accorded capital treatment, and therefore they were forced to develop their own criteria. The large variety of factual situations which were litigated resulted in a lack of uniformity as to what the proper criteria should be. A number of decisions seem to have been based on the presence of one or a few factors, ${ }^{7}$ but a majority of the cases, particularly the more recent ones, have indicated that the "net effect" of a multitude of factors is determinative. ${ }^{8}$

1. Int. Rev. Code of 1939, $\$ 115$ (a), as amended, 61 Stat. 179 (1947).

2. Section 22(a) defined gross income as including dividends. Id. $\$ 22(\mathrm{a})$, as amended, 53 Stat. 9 (1939) (now INT. Rev. Code of 1954, $\$ 61$ (a) (7)).

3. Int. Rev. Code of 1939, §115(c), 52 Stat. 496 (1938).

4. Id. $\$ 115(\mathrm{i}), 52$ Stat. 498 (1938).

5. Id. $\$ 115(\mathrm{~g})(1)$, as amended, 64 STAT. 931-32 (1950). The general provision contained herein will be referred to in the text by its more familiar appellation of $115(\mathrm{~g})$. The balance of the section as it stood in the old Code was added by the 1950 Revenue Act (Revenue Act of 1950, $\$ 208$ (a), 209(a), 64 STAт. 931-32) and contained provisions relating to redemptions through the use of a subsidiary corporation and redemptions to pay death taxes. Int. Rev. Code of $1939, \S 115(\mathrm{~g})(2), 64$ STAT. 932 (1950) (now INT. REV. CODE OF 1954, § 303); id. \$115(g)(3), as amended, 65 STAT. 498 (1951) (now INT. REv. CODE OF 1954, § 304).

For a discussion of the history of $\$ 115(\mathrm{~g})$, see Darrell, Corporate Liquidations and the Federal Income Tax, 89 U. of PA. L. REv. 907, 912-913 (1941); Murphy, Partial Liquidations and the New Look, 5 TAX L. REv. 73, 75-76 (1950).

6. See generally Bittker \& Redlich, Corporate Liquidations and the Income Tax, 5 TAX I. REV. 437, 465 (1950).

7. E.g., Commissioner v. Quackenbos, 78 F.2d 156 (2d Cir. 1935) ; Rosemary C. Weir Trust, P-H 1952 T.C. Mem. Dec. I52199; Carter Tiffany, 16 T.C. 1443 (1951) nonacq., 1951-2 Cum. Bull. 6; A. E. Levit, 43 B.T.A. 1077 (1941); J. Natwick, 36 B.T.A. 866 (1937) ; George A. Lembcke, 33 B.T.A. 700 (1935), nonacq., XV-I Cuns. BurL. 37 (1936).

8. E.g., Commissioner v. Sullivan, 210 F.2d 607 (5th Cir. 1954); Keefe v. Cote, 213 F.2d 651 (1st Cir. 1954); Boyle v. Commissioner, 187 F.2d 557 (3d Cir.), 
In concluding that a distribution was essentially equivalent to a dividend, the courts seemed to emphasize the following factors: the distribution was made pro rata among the shareholders, ${ }^{9}$ the stock which was redeemed had been issued as a dividend shortly before the redemption, ${ }^{10}$ the corporation had paid no dividends or few dividends in the past, ${ }^{11}$ there had been a large surplus for a number of years prior to the distribution, ${ }^{12}$ and the distribution was instigated by the shareholders. ${ }^{13}$

The cases in which the distribution was held to be not essentially equivalent to a dividend seemed to stress the following reasons: few of the factors mentioned above were present, ${ }^{14}$ the distribution was disproportionate among the shareholders, ${ }^{15}$ the redemption terminated the taxpayer's interest in the corporation, ${ }^{16}$ the stock was redeemed at a price equal to its book value, ${ }^{17}$ and there was a legitimate business reason for making the distribution. ${ }^{18}$ The courts seemed to place more emphasis on the presence of a valid business reason than on any other single factor. A valid business purpose was found in cases in which the redemption resulted from a legitimate contraction of the corporate business, ${ }^{19}$ from the instigation of

cert. denied, 342 U.S. 817 (1951); Commissioner y. Snite, 177 F.2d 819 (7th Cir. 1949); Flanagan v. Helvering, 116 F.2d 937 (D.C. Cir. 1940); Estate of Charles D. Chandler, 22 T.C. 1158 (1954); A. C. Monk, P-H 1947 T.C. Mem. Dec. fl 47247.

9. Boyle v. Commissioner, 187 F.2d 557 (3d Cir.), cert. denied, 342 U.S. 817 (1951) ; Rheinstrom v. Conner, 125 F.2d 790 (6th Cir. 1942) ; Flanagan v. Helvering, 116 F.2d 937 (D.C. Cir. 1940).

10. Arthur M. Godwin, 34 B.T.A. 485 (1936), acq., XV-2 Cum. Bulz. 10 (1936); James D. Robinson, 27 B.T.A. 1018, aff'd, 69 F.2d 972 (5th Cir. 1934).

11. Fostoria Glass Co. v. Yoke, 45 F. Supp. 962 (N.D.W. Va. 1942) ; Boyle v. Commissioner, 187 F.2d 557 (3d Cir.), cert. denied, 342 U.S. 817 (1951). See also Meyer v. Commissioner, 5 T.C. 165 (1945), remanded, 154 F.2d 55 (3d Cir.), on remand, 7 T.C. 1381 (1946).

12. E.g., Rheinstrom v. Conner, 125 F.2d 790 (6th Cir. 1942) ; G.C.M. 11304, XII-1 Cum. Bull. 135 (1933); cf. Joseph W. Imler, 11 T.C. 836 (1948), acq., 1949-1 CUMM. BULI. 2.

13. E.g., A. E. Levit, 43 B.T.A. 1077 (1941).

14. E.g., Estate of Ira F. Searle, P-H 1950 T.C. Mem. Dec. I50261; A. C. Monk, P.H 1950 TC Mem. Dec. If 47247; Favrot v. Scofield, 53-1 U.S.T.C. I 9427 (W.D. Tex. 1953); Heber Scowcroft Investment Co. v. Commissioner, P-H 1945 T.C. Mem. Dec. If 45235; Bona Allen, Jr., 41 B.T.A. 206 (1940); Harry A. Koch, 26 B.T.A. 1025 (1932).

15. E.g., R. W. Creech, 46 B.T.A. 93 (1942), acq., 1942-1 Cum. ButL. 4; Rosemary C. Weir Trust, P-H 1952 T.C. Mem. Dec. โ 52199.

16. Zenz v. Quinlivan, 213 F.2d 914 (6th Cir. 1954); Carter Tiffany, 16 T.C. 1443, (1951), nonacq., 1951-2 CuM. BULL. 6; cf. Clara Louise Flinn, 37 B.T.A. 1085 (1938), acq., 1938-2 Cum. Buls. 11. But cf. Hirsch v. Commissioner, 124 F.2d 24 (9th Cir. 1941).

17. E.g., A. C. Monk, P-H 1947 T.C. Mem. Dec. $\llbracket 47247$.

18. See cases cited in notes 19-21 infra.

19. Commissioner v. Sullivan, 210 F.2d 607 (5th Cir. 1954); Commissioner v. Champion, 78 F.2d 513 (6th Cir. 1935) ; Commissioner v. Babson, 70 F.2d 304 (7th Cir.), cert. denied, 293 U.S. 571 (1934); Estate of Charles D. Chandler, 22 T.C. 1158 (1954); Clarence R. O'Brion, P-H 1951 T.C. Mem. Dec. II 51373; Joseph W. Imler, 11 T.C. 836 (1948), acq., 1949-1 CuM. BunL. 2; L. M. Lockhart, 8 T.C. 436 (1947) ; Samue1 A. Upham, 4 T.C. 1120 (1945), acg., 1945 Cum. Buld. 7; Heber Scowcroft Investment Co., P-H 1945 T.C. Mem. Dec. $\Uparrow 45235$. 
a creditor of the corporation, ${ }^{20}$ and from the desire to have stock available for sale to employees. ${ }^{21}$

A typical example of the "net-effect" approach can be seen in the case of A.C. Monk ${ }^{22}$ in which the Tax Court said:

"No one element is of conclusive importance but the confluence of all these factors in a single situation plus the regular distribution of cash dividends of $15 \%$ to $50 \%$; the considerable though not drastic reduction of the petitioner's proportionate stock interest which will reflect itself notably in future dividend distributions; the origin of the initiative for the redemption in the creditor banks and the reluctance of petitioner to agree to it; the importance to the corporation of the result achieved; the payment for the stock at book value, which was greatly in excess of petitioner's cost; the fact that no stock dividend had ever been distributed by the corporation; the prior history of petitioner's repayment in cash in each year of loans obtained from the corporation; plus the peculiar and compelling background of this case, all seem to place it well beyond the intended orbit of section $115(\mathrm{~g}) . " 23$

At least one court has correctly recognized that the use of the term "net effect" to cover this treatment is in actuality merely a restatement of the phrase "essentially equivalent to a dividend." 24

One conclusion which is evident in reviewing the numerous decisions under Section $115(\mathrm{~g})$ is that the courts applied no definite, uniform tests in ascertaining which redemptions were essentially equivalent to a dividend and which were not. Although many of the cases emphasized that the basic criterion was the net effect of the redemption, rather than the intent of the shareholders or the corporation, ${ }^{25}$ the various factors examined in determining the net effect indicate that the reason or motive for making the distribution was, in reality, considered to be of primary importance. ${ }^{26}$

\section{The Statutory Scheme of the 1954 Code}

In the 1954 Code, Section 301 is the basic provision dealing with distributions of property from a corporation to a shareholder with respect to its stock. This section states that, except as otherwise provided, the portion of such a distribution which is a dividend shall be included in gross income and the portion which is not a dividend shall first be applied against and reduce the basis of the stock and then the remainder shall be treated

20. Bona Allen, Jr., 41 B.T.A. 206 (1940) ; Isaac C. Eberly, P-H 1951 T.C. Mem. Dec. I 51351; A. C. Monk, P-H 1947 T.C. Mem. Dec. I 47247; William W. Wood, 3d. P-H 1943 T.C. Mem. Dec. $₫ 43488$.

21. H. F. Asmussen, 36 B.T.A. 878 (1937), acq., 1938-1 Cur. Bul.. 12; Commissioner v. Snite, 177 F.2d 819 (7th Cir. 1949).

22. P-H 1947 T.C. Mem. Dec. \ 47247.

23. Id. at pp. 1020-21.

24. Commisioner v. Sullivan, 210 F.2d 607, 609 (5th Cir. 1954). See Commissioner v. Snite, 177 F.2d 819 (7th Cir. 1949).

25. See cases cited in note 8 supra.

26. See Keefe v. Cote, 213 F.2d 651, 657 (1st Cir. 1954). 
as gain from the sale or exchange of property. ${ }^{27}$ As under the 1939 Code, a dividend is defined in Section 316(a) as any distribution of property by a corporation to its shareholders out of its earnings and profits of the taxable year or out of its earnings and profits accumulated since February 28, 1913. This provision also specifies that, except as otherwise provided, every distribution is made out of earnings and profits to the extent thereof. Therefore, the effect of the 1954 Code is similar to that of the prior law, because, unless there is a specific provision to the contrary, every distribution from a corporation to its shareholders will be considered a dividend and thus will be taxed as ordinary income so long as the corporation has either current or accumulated earnings and profits. As under the 1939 Code, certain distributions in redemption of stock constitute an exception to this general treatment and are taxed as capital transactions, despite the presence of earnings and profits. ${ }^{28}$ However, the new Code has made a basic change by splitting those distributions which formerly were covered by the old Sections 115 (c) and $115(\mathrm{~g})$ into two parts-one providing for distributions in redemption of stock ${ }^{29}$ and the other providing for distributions in partial liquidation of the corporation. ${ }^{30}$ Apparently, the distinction to be drawn is that qualification under the former is determined solely by the effect of the distribution on the shareholders, while qualification under the latter is determined solely by the effect of the distribution on the corporation. ${ }^{31}$

\section{Redemptions}

A redemption of stock is defined in Section $317(b)$ as an acquisition by a corporation of its stock from a shareholder in exchange for property, whether or not the stock is cancelled, retired or held as treasury stock. ${ }^{32}$ Amounts received in redemption of stock are taxed as capital gain or loss by Section 302 (a) if the redemption qualifies under one of the four condi-

27. INT. Rev. CODE of 1954, $\S 301$ (a), (c).

28. $I d . \$ 302,346$.

29. Id. $\S 302$.

30. Id. $\$ 346$.

31. See text at notes $54-55$ infra.

32. Apparently, the purpose of this latter phrase was to overrule the cases under prior law which held that, if the corporation placed the acquired stock in its treasury, there was a "sale" of stock to the corporation rather than a redemption. See SEN. REP. No. 1622, 83d Cong., 2d Sess. 252 (1954) (hereinafter cited SEN. REP.).

A characterizing of corporate acquisitions of its own stock as a "sale" may have arisen as a judicial amelioration of the treatment of distributions in partial liquidation as short term capital gain in the Revenue Acts between 1934 and 1942. See Bittker \& Redlich, stipra note 6 , at 451. For a general description of the tax treatment of partial liquidations during the 1934-1942 period see 1 Mertens, Federal InCOME TAXATron $\$ 9.122$ (Cum. Supp. 1954); Bittker \& Redlich, supra note 6, at 458-59. See Estate of Charles C. Ingalls, 45 B.T.A. 787 (1941), nonacq., 1942-1 Cum. Bull. 21, aff'd, 132 F.2d 862 (6th Cir. 1943). Holding a redemption was actually a sale meant that the amount received would be treated as a long term capital gain. See, e.g., Alpers v. Commissioner, 126 F.2d 58 (2d Cir, 1942); R. W. Creech, 46 B.T.A. 93 (1942), acq., 1942-1 CuM. Bult. 4; W. C. Robinson, 42 B.T.A. 725 (1940); William A. Smith, 38 B.T.A. 317 (1940); cf. Commissioner v. Snite, 177 F.2d 819 (7th Cir. 1949) (applying the law after 1942). 
tions set forth in Section 302(b). Three of these are specific examples ${ }^{33}$ and the fourth, ${ }^{34}$ which is derived from the old Section $115(\mathrm{~g})$, states that the redemption must not be essentially equivalent to a dividend.

The first of the specific examples provides that the distribution must be "substantially disproportionate," 35 and this phrase is carefully defined to mean that the redemption must result in a specified decrease in the shareholder's ownership of both voting stock and common stock. It is provided that immediately after the redemption the ratio which the voting stock owned by the shareholder bears to all of the voting stock of the corporation must be less than 80 percent of the same ratio before the redemption, ${ }^{36}$ and this same test must be met with respect to the shareholder's common stock. ${ }^{37}$ As a further limitation, it is provided that after the redemption the shareholder cannot own 50 percent or more of all of the classes of voting stock. $^{38}$ To insure against the possibility of taxpayer abuse, it is also specified that a substantially disproportionate redemption will not qualify under this test if it is one of a series of redemptions which in the aggregate will not result in a substantially disproportionate redemption. ${ }^{30}$ In order for a distribution to qualify under the second specific example, the shareholder's interest in the corporation must be terminated by a redemption of all of his stock. ${ }^{40}$ The third example is a technical provision of limited application, since it is concerned with redemptions of stock by railroads pursuant to a plan of reorganization under Section 77 of the Bankruptcy Act. ${ }^{41}$

All four tests of Section 302(b) are subject to the new and important provisions of Section 318 respecting attribution of ownership of stock. ${ }^{42}$ Essentially under this section, a taxpayer is considered as owning stock held by his spouse, children, grandchildren and parents, and by partnerships, estates, trusts and corporations in which he has a specified interest.

33. See text at and following note 35 infra. infra.

34. INT. Rev. Code of 1954, $\$ 302$ (b) (1). See text at and following note 56

35. Id. $\$ 302(\mathrm{~b})(2)(\mathrm{A})$.

36. $I d . \S 302(\mathrm{~b})(2)(\mathrm{C})$.

37. Ibid.

38. Id. $\$ 302(\mathrm{~b})(2)(B)$. The Senate Finance Committee describes this as a "further safeguard." SEN. RkP. 45.

39. INT. Rev. CODE OF 1954, § 302(b) (2) (D). See Boyle v. Commissioner, 187 F.2d 557 (3d Cir.), cert. denied, 342 U.S. 817 (1951).

40. INT. REv. CODE OF 1954, §302(b) (3).

41. Id. $\$ 302(\mathrm{~b})(4)$.

42. Id. \$302(c) (1). See U.S. Treas. Proposed Reg. \$1.302-1, 19 Fed. Reg. 8239 (1954). But compare Cohen, Redemptions of Stock Under The Internal Revenue Code of 1954, 103 U. of PA. L. REv. 739, 758-59 (1955).

The rules of attribution of ownership of stock are new in the 1954 Code; however, the Treasury did attempt to introduce the concept into the old Code by a proposed amendment to the regulations under $\$ 115(\mathrm{~g})$. See U.S. Treas. Proposed Reg., 16 FED. REG. 10312 (1951). But cf. Estate of Ira F. Searle, P-H 1950 T.C. Mem. Dec. If 50261. Similar rules were applied under the 1939 Code to collapsible corporations (U.S. Treas. Reg. 118, $\$ 39.117(\mathrm{~m})-1(\mathrm{c})(2)(1953)$ ) and in determining whether a corporation was a personal holding company (Int. Rev. Code of 1939, $\S 503,52$ STAт. 559 (1938)). 
The theory for introducing these provisions into the Code seems to be that, although normally a shareholder's equity interest in a corporation may be basically changed by a redemption of some of his stock, in reality it may not be basically changed where closely related interests continue to hold stock in the corporation. ${ }^{43}$ One exception to the family ${ }^{44}$ attribution rules is made where a shareholder wishes to terminate his interest in the corporation while permitting other members of his family to continue to own stock in it. Section 302 (c) (2) provides that in such a case a redemption of the shareholder's stock will qualify under Section 302 (a) if the following conditions are met: (1) after the redemption the shareholder has no interest in the corporation other than as a creditor, (2) he does not acquire an interest other than by inheritance for ten years thereafter, (3) he had not acquired within the ten-year period prior to the redemption stock from a person whose stock would be attributed to him in a transaction having tax avoidance as a principal purpose, (4) such a person had not acquired stock from the shareholder within the same period in a transaction having tax avoidance as a principal purpose, and (5) he complies with the regulations prescribed by the Secretary.

\section{Partial Liquidations}

Section 331(a)(2) of the new Code specifies that distributions in partial liquidation are to receive capital gain or loss treatment, and Section 346 defines partial liquidations. The pattern of Section 346 is similar to Section 302 in that there is a general standard ${ }^{45}$ followed by a specific example. ${ }^{46}$ The general standard again draws on the dividend equivalence test of Section $115(\mathrm{~g})$ of the 1939 Code. A distribution in redemption ${ }^{47}$ of part of the stock of a corporation qualifies as a partial liquidation if it is not "essentially equivalent to a dividend" and it is made pursuant to a plan and within a prescribed period. There is also, as in the old Code, a provision that one of a series of distributions in redemption of all of the stock of the corporation qualifies as a partial liquidation. ${ }^{48}$ A distribution comes within the specific example if all of the following conditions are met: (1) the distribution is attributable to the corporation's ceasing to conduct a trade or business, or it consists of the assets of a trade or business, (2)

43. See A.L.I. Fed. Income TAx Stat. 274 (Feb. 1954 Draft). Compare the theory expressed in Estate of Ira F. Searle, P-H 1950 T.C. Mem. Dec. If 50261.

44. This exception does not apply to the other rules of attribution of ownership of stock. See note 83 infra.

45. INT. REv. CoDE of 1954, \$346(a) (2). See text following note 66 infra.

46. $I d$. $\S 346(\mathrm{~b})$.

47. Although $\$ 346$ uses the word "redemption," the definition of this word in $\$ 317$ (a) does not by its terms apply to the part of subchapter $C$ which deals with corporate liquidations. Thus, it is conceivable that the "sale or redemption" argument (see note 32 supra) could be read into $\$ 346$. However, the proposed regulations seem to assume that the definition applies to all of subchapter C (U.S. Treas. Proposed Reg. $\$ 1.317-2,3,4,19$ FED. REG. 8254 (1954)), and this appears to be a more reasonable reading of the Code.

48. INT. Rev. CODE of 1954, §346(a) (1). 
after the distribution, the corporation actively conducts a trade or business, (3) both trades or businesses were actively conducted throughout the fiveyear period prior to the distribution, and (4) neither of the trades or businesses was acquired within this five-year period in a transaction in which gain or loss was recognized. In contrast to redemptions under Section 302, the rules as to constructive ownership of stock are not applied to partial liquidations. ${ }^{49}$

\section{The Dividend Equivalence Tests of Sections 302 and 346}

Under the House Bill ${ }^{\mathbf{5} 0}$ the dividend equivalence standard was eliminated, and, in order for a distribution to qualify for capital treatment, it had to meet the requirements of one of the carefully defined tests which were set forth in two provisions-one dealing with redemptions and the other with partial liquidations. The aims of the House Ways and Means Committee were to make prior law more definite and to prevent tax avoidance devices which had received judicial sanction under the 1939 Code..$^{51}$ Although the Senate shared these views, it concluded that flexibility should not be completely sacrificed for legislative certainty. ${ }^{52}$ The final result was that the House approach of setting forth specific examples in separate statutory provisions was continued but that the preciseness of the House Bill was destroyed by introducing the broad dividend equivalence test of the prior code into each section. ${ }^{53}$

The Senate Finance Committee Report states that, in interpreting Section 302, the examination is to be limited to what has occurred on the shareholder level and that the interpretation of Section 346 is to be conducted solely on the basis of what has taken place on the corporate level. ${ }^{54}$ This seems to be the only logical inference which can be drawn from the statute itself, because there appears to be no other reason for having divided those transactions which formerly were covered by Sections 115 (c) and $115(\mathrm{~g})$ into two statutory provisions. Moreover, the substantially disproportionate test and the termination of interest test of Section 302 are directed toward the effect of the distribution on the shareholder, whereas the two-business example of Section 346 is directed toward certain activities of the corporation, without regard to the effect on the shareholder. ${ }^{55}$ In conformity with this approach of the Senate Report, a redemption of stock under Section 302 would be considered on a shareholder-by-shareholder basis, and, therefore, when a corporation redeems the stock of a number of its shareholders, the distributions to some of them may be taxed 262.

49. U.S. Treas. Proposed Reg. §1.346-2, 19 Fed. REg. 8268 (1954) ; SEN. ReP.

50. H.R. 8300, 83d Cong., 2d Sess. \$\$ 302, 336(a) (1954).

51. H.R. Rep. No. 1337, 83d Cong., 2d Sess. 34 (1954).

52. SEN. REP. 41-42.

53. See Murphy, Dividend Equivalence-The End of the Beginning?, 10 TAx L. REv. 213 (1955).

54. SEN. REP. 49.

55. Section $346(b)$ states that whether or not a distribution meets the twobusiness test ". . . shall be determined without regard to whether or not the distribution is pro rata with respect to all of the shareholders of the corporation." 
as a dividend even though the distributions to others are treated as capital transactions. On the other hand, all of the shareholders who receive a portion of a distribution would be taxed in the same manner if the transaction is considered under Section 346 , since the examination is made solely on the corporate level.

It is not clear, however, what circumstances are to be examined in order to determine under Section 302(b) (1) whether or not the effect on the shareholder is such as to make the distribution essentially equivalent to a dividend. The Senate Report states that in general the test is to be the one which was employed under Section $115(\mathrm{~g}){ }^{56}$ But this does not provide an easy solution, since the decisions under the 1939 Code were not focused solely at the shareholder level or the corporate level, but were based on a number of factors, some of which had an effect on the shareholders and some of which had an effect on the corporation. ${ }^{57}$ Nevertheless, it is apparent that under the prior law one reason for taxing a redemption as a dividend was that it was made pro rata among the shareholders ${ }^{88}$ and two reasons for taxing a redemption as a capital transaction were that it terminated the shareholder's interest in the corporation ${ }^{59}$ or that it was non-pro rata. ${ }^{60}$ The Proposed Regulations indicate that ordinarily pro rata redemptions will not come within the dividend equivalence test of Section 302. ${ }^{\text {.1 }}$ Since one of the specific examples provides automatic capital treatment for a shareholder whose interest in the corporation has been terminated by the redemption ${ }^{22}$ and since the substantially disproportionate test prescribes the same treatment for one type of non-pro rata redemption, $^{63}$ it would seem that distributions which will qualify under the dividend equivalence standard of Section 302 will be limited almost completely to certain modifications of these specific examples. ${ }^{64}$ The Senate Report also states that "in applying [the test employed under Section $115(\mathrm{~g})$ ] . . . the inquiry will be devoted solely to the question of whether or not the transaction by its nature may properly be characterized as a sale of stock by the redeeming shareholder to the corporation." 65 Although the meaning of this statement is in doubt, a possible interpretation is that any redemption which would otherwise come within the dividend equivalence test of Section 302 will be taxed as ordinary income if it was not a bona fide transaction and was undertaken for the purpose of tax avoidance. ${ }^{68}$

56. SEN. ReP. 234.

57. See text following note 6 supra.

58. See text at note 9 and note 9 supra.

59. See text at note 16 and note 16 supra.

60. See text at note 15 and note 15 supra.

61. U.S. Treas. Proposed Reg. $\$ 1.302-2(b), 19$ Fed. REg. 8239 (1954). See the discussion in text following note 145 infra.

62. INT. Rev. CoDE of 1954, §302(b) (3).

63. Id. $\$ 302(\mathrm{~b})(2)$.

64. But see text at notes $80-89$ infra and text following note 145 infra.

65. SEN. REP. 234.

66. After this phrase, the Report states that in making this determination the presence or absence of earnings and profits is immaterial. Ibid. However, this would seem to affect primarily deficit corporations. See Cohen, supra note 42 , at 744. 
The Senate was somewhat more precise as to what should be considered on the corporate level in determining whether a distribution meets the dividend equivalence test of Section 346. The Finance Committee Report states that:

"Primarily this definition [of partial liquidation] involves the concept of 'corporate contraction' as developed under existing law. . . . It is intended that a genuine contraction of the business as under present law will result in partial liquidation." ${ }^{67}$

Although it is not clear from the cases decided under Section $115(\mathrm{~g})$ what constitutes a "genuine contraction," 88 there are several statements in the Statute and Report which indicate the types of situations which may be held to fall within the meaning of this term. In the first place, Section 346 (a) (2) provides that the two-business test of subsection (b) is an example of a distribution which is not essentially equivalent to a dividend. This indicates that some cases in which there is a contraction resulting from the liquidation of one of two businesses may qualify under the dividend equivalence test although they do not meet all of the requirements of the specific example. Secondly, both the Senate Report ${ }^{69}$ and the Proposed Regulations ${ }^{70}$ specify that the case of Joseph $W$. Imler ${ }^{71}$ is one example which will qualify as a genuine contraction and that a distribution of a reserve for expansion will not qualify. In ascertaining whether or not a particular set of circumstances constitutes a genuine contraction, the courts probably will analyze it in light of the factors present in these two types of situations.

There is no clear indication as to whether the inquiry on the corporate level can extend beyond the question of corporate contraction. However, the Senate Report states only that the definition of partial liquidation primarily involves the concept of corporate contraction, ${ }^{72}$ and the Proposed Regulations are to the same effect. ${ }^{73}$ Moreover, the use of the same general test in Section 346(a) as was employed in the 1939 Code may prompt the courts to apply the prior case law, particularly the business purpose test, ${ }^{74}$ to the cases arising under the new Code.

\section{Overlapping Distributions}

The final problem to be considered in interpreting the statutory scheme involves distributions which meet the requirements of one of the specific examples and also qualify under the dividend equivalence test and distribu-

67. SEN. REP. 262.

68. See text at notes 121-33 infra.

69. SEN. REP. 262.

70. U.S. Treas. Proposed Reg. §1.346-1 (a), 19 FED. REg. 8267 (1954).

124 infra.

71. 11 T.C. 836 (1948), acq., 1949-1 CuM. Bull. 2. See text following note

72. See text at note 67 supra.

73. U.S. Treas. Proposed Reg. §1.346-1(a), 19 FED. REG. 8267 (1954).

74. See text at and following note 18 supra. 
tions which come within both Section 302 and Section 346. Any case which qualifies under the two-business test of Section 346(b) will also qualify under the dividend equivalence standard of Section $346(a),{ }^{75}$ and there is no advantage to the taxpayer to argue that the distribution falls under the latter provision, since the result in either case would be the same. Section 302(b) (5) provides that failure to meet the requirements of any of the specific examples of Section 302 is not to be taken into account in considering whether a transaction qualifies under the dividend equivalence test of Section 302(b)(1). ${ }^{76}$ If a redemption terminates the taxpayer's interest in the corporation and also comes within Section $302(\mathrm{~b})(1)$, it is to the taxpayer's advantage to contend that the redemption should be treated under the latter provision, because it is not subject to the restriction as to the acquisition of an interest in the corporation within the ten years following the redemption. ${ }^{77}$ If a distribution falls within both Sections 302 and 346 , it is to be taxed under the latter provision. ${ }^{78}$ However, it is possible for a portion of a distribution to qualify under Section 346 and the remainder under Section 302.79 But, since the rules of constructive ownership of stock are applicable to Section 302 and not to Section 346, the taxpayer should maintain in every case in which these rules might apply that the distribution to him comes within the latter section.

\section{Specific Applications of the 1954 Code}

Although the 1954 Code retains the dividend equivalence standard of the 1939 Code, it would seem to create certain new problems because of the separate treatment of redemptions and partial liquidations and because of the insertion of the specific examples in both Sections 302 and 346 . In order to point out some of these problems, an analysis of the dividend equivalence test will now be explored through a series of hypothetical cases which are based primarily on situations that arose under the 1939 Code.

\section{Distributions Under Section 302}

Redemptions Not Qualifying under the Specific Examples.-Corporation $X$ has issued only one class of stock of 100 shares. $A$ owns 50 shares, $A$ 's son owns 25 shares, and the remaining 25 shares are owned by a trust in which $A$ has a life estate. The trust was set up under the will of $A$ 's former business associate, who was a bachelor, and has been administered by a trustee who has voted the stock and acted completely independent of $A$. A person, unrelated to $A$, is the remainderman of the trust, and $A$ 's life estate, computed on an actuarial basis, is a 15 percent interest. ${ }^{80}$ Corporation $X$ redeems $A$ 's 50 shares.

75. See text following note 68 supra.

76. INT. REv. CODE OF 1954, §302(b) (5).

77. Id. $\$ 302(\mathrm{c})(2)$. (1954).

78. Id. $\$ 346$ (c); U.S. Treas. Proposed Reg. \$1.346-2, 19 FED. REg. 8268

79. U.S. Treas. Proposed Reg. $\$ 1.302-1,19$ FED. REG. 8239 (1954).

80. See U.S. Treas. Proposed Reg. \$1.318-3(d), 19 FED. REG. 8256 (1954). 
If this case had been decided under the 1939 Code, the redemption would not have been taxed as a dividend, because $A$ would not have been considered as owning his son's stock or that of the trust, ${ }^{81}$ and thus the redemption would have terminated his interest in the corporation. However, under the 1954 Code the redemption of $A$ 's stock cannot qualify under the termination of interest test of Section 302(b) (3) because of the operation of the rules attributing ownership of stock. Although Section 302 (c) (2) would permit $A$ 's interest in the corporation to be terminated despite his son's continued ownership of stock, ${ }^{82}$ it does not apply to the shares owned by the trust; therefore, $A$ still has attributed to him 15 percent of the stock held in trust, or 3.75 shares. ${ }^{83}$ Moreover, the attribution of ownership rules prevent this redemption from qualifying under the substantially disproportionate test of Section 302(b)(2), because Section 302 (c) (2) is not applicable to this provision and thus $A$ will be considered as owning his son's 25 shares as well as 3.75 of the shares held by the trust. Consequently, although the redemption comes within the 80 percent ratio requirement, ${ }^{84}$ it fails to meet the limitation that $A$ own less than 50 percent of the voting stock following the redemption. ${ }^{85}$

Since the redemption to $A$ fails to come within either of the specific tests, the question arises as to whether it would qualify under the dividend equivalence standard of Section 302(b) (1). A could advance two arguments that the distribution to him should come within the dividend equivalence test. First he could point out that the only reason the redemption fails to qualify as terminating his interest is because of the constructive ownership of 3.75 of the shares held in trust, and that, since he does not have control over the activities of the trustee, he would not have been able to force the latter to dispose of the stock held by the trust. Therefore, it could be maintained that the redemption should qualify as not being essentially equivalent to a dividend on the basis that $A$ has made a bona fide attempt to terminate his interest, which was Congress' aim when it inserted the attribution of ownership provisions. ${ }^{86}$ This situation is dis-

81. Cf. Clara Louise Flinn, 37 B.T.A. 1085, 1094 (1938), nonacq., 1938-2 CuM. BulL. 43. See the reasoning in Estate of Ira F. Searle, P-H 1950 T.C. Mem. Dec. II 50261, an extreme application of which can be found in John T. Roberts, 17 T.C. 1415, 1419 (1952), revd, 203 F.2d 304 (4th Cir. 1953). Where the remaining shareholders were unrelated individuals the termination of a shareholder's interest under the 1939 Code was considered as falling without the ban of $\$ 115(\mathrm{~g})$. Compare Carter Tiffany, 16 T.C. 1443 (1951), nonacq., 1951-2 CuM. Bull. 6, with Boyle v. Commissioner, 187 F.2d 557 (3d Cir.), cert. denied, 342 U.S. 817 (1951).

82. INT. REV. CODE OF 1954, §302(c) (2).

83. U.S. Treas. Proposed Reg. $\$ 1.302-4(f), 19$ FED. REG. 8240 (1954). No reason is given in the Senate Report for limiting the exception to cases of family ownership of stock.

84. Before the redemption $A$ is considered as owning his own 50 shares, his son's 25 shares and 3.75 shares held by the trust or $78.75 \%$ of the stock of Corporation $X$. Following the redemption $A$ is treated as owning 28.75 shares or $57.54 \%$ of the stock. This latter ratio is less than $80 \%$ of the previous ratio. See INT. Rev. CODE of 1954, §302(b) (2) (C).

85. Id. $\S 302(\mathrm{~b})(2)(\mathrm{B})$.

86. See SEN. REp. 45. 
tinguishable from a case in which a second corporation, Corporation $Y$, holds the 25 shares and $A$ owns 51 percent of the stock of this second corporation. In such an instance, the constructive ownership rules would attribute to $A 51$ percent of the 25 shares in Corporation $X .^{87}$ The factor which differentiates this case from the one in which the trust holds the 25 shares is that $A$, by his control of Corporation $Y$, can force it to dispose of the 25 shares held in Corporation $X$, and thus he has not done all within his power to terminate his interest in Corporation $X$. A's second argument would be that, since the dividend equivalence test was inserted by the Senate to permit some flexibility because the mathematical precision of the standards in the House Bill "appeared unnecessarily restrictive," 88 a case which almost meets the requirements of the termination of interest test should qualify as not being essentially equivalent to a dividend. The weakness of both of these arguments is that Section 302 sets forth a definite method by which a shareholder can qualify for capital treatment by terminating his interest in the corporation. When, as in this case, the shareholder fails to come within this test, it can be maintained that the transaction should be taxed as a dividend or the specific examples will have little meaning. Furthermore, if the redemption were held to be within the dividend equivalence test, $A$ would be in a more advantageous position than if it had come within the termination of interest test, because the restriction with respect to $A$ 's acquiring an interest in Corporation $X$ for the ten-year period following the redemption applies only to the latter provision. ${ }^{89}$ Thus, where the Statute specifically allows an exception to the constructive ownership rules, $A$ would be in a more restricted position than where it makes no exception.

Basically, this situation presents a dilemma. If the cases which are close to the specific tests are held to be within the dividend equivalence standard, the former have little meaning. On the other hand, if these cases are not treated as within the dividend equivalence test, it has little meaning; since qualification under Section 302 is limited to an examination of the effect of the distribution on the shareholder level, the dividend equivalence test of this section would seem to be limited to cases in which there is some change in the shareholder's interest in the corporation, and such cases are, in effect, modifications of the specific examples. ${ }^{90}$ This dilemma is emphasized in the hypothetical example, because, as was pointed out above, the taxpayer could avoid the restriction as to acquiring an interest in the corporation by having the distribution to him treated under the dividend equivalence standard.

The Code suggests a method of avoiding this dilemma. Section 302 (b) (5) provides that "in determining whether a redemption meets the requirements of [the dividend equivalence test] . . ., the fact that it

87. INT. REv. CODE OF 1954, \$318(a) (2) (C).

88. SEN. REP. 44. See text at notes 50-53 supra.

89. INT. REv. CODE of $1954, \S 302$ (c) (1), (2).

90. See text at notes 62-64 supra. 
fails to meet the requirements of . . . [the specific examples] shall not be taken into account." ${ }^{91}$ The conclusion is that the specific tests are of little effect, except to give capital treatment to transactions coming exactly within them and to provide an indication of the proper interpretation to be placed on the dividend equivalence test. The dilemma, therefore, is merely avoided but not removed.

Use of Surplus in the Sale of the Corporation.- $A$ and $B$ own the $X$ Corporation which they wish to sell to $C$ and $D$. The corporation has a large earned surplus and possesses a large amount of readily distributable assets, including cash and Government bonds. Both $C$ and $D$ are unable to pay for the large surplus and are unwilling to acquire it because of attendant tax liabilities. Accordingly, $C$ and $D$ purchase 20 percent of $A$ 's and $B$ 's stock for an amount equal to the value of the corporation's operating assets, and $A$ and $B$ agree to have the corporation redeem the remaining shares of their stock.

This situation is essentially the same as the one presented in Zenz $v$. Quinlivan ${ }^{92}$ and it raises problems of the proper tax treatment of both $A$ and $B$ and $C$ and $D$. It will be considered first from the standpoint of the sellers and then from that of the buyers. Under the 1939 Code $^{93}$ the redemption of the sellers' stock probably would not have been held to be equivalent to the distribution of a dividend to them, even though it was pro rata and there was no business purpose, since it terminated their interests in the corporation. ${ }^{94}$ However, if the situation was reversed and the 80 percent of the stock was first redeemed by the corporation and then the balance of the stock was sold to $C$ and $D$, the result under the 1939 Code was not as clear, there being a much greater possibility that the redemption would have been subject to tax as a dividend, since it did not terminate the interests of $A$ and $B$, it was made pro rata and there was no business purpose. ${ }^{95}$ The 1954 Code would seem to perpetuate this distinction. Where the stock is sold first and then the redemption occurs, the transaction would fit within the termination of interest test of Section 302(b) (3). On the other hand, if the events occur in the reverse order, it would seem more probable that the distribution to $A$ and $B$ would be taxed under Section 301. The distribution is made pro rata to $A$ and $B$ and therefore effects no change on the shareholder level, which would seem to be required for qualification under the dividend equivalence standard of Section 302 unless this test encompasses some pro rata redemptions because of the showing of

91. INT. REv. CODE of 1954, §302(b) (5).

92. 213 F.2d 914 (6th Cir. 1954), acq., Rev. Rul. 458, 1954 INT. Rev. BulL. No. 42 , at 15 . (1954).

93. The law under the 1939 Code is discussed in Note, 67 HARv. L. REv. 1387

94. Zenz v. Quinlivan, 213 F.2d 914 (6th Cir. 1954) ; cf. Carter Tiffany, 16 T.C. 1443 (1951), nonacq., 1951-2 Cun. BuLr. 6.

95. Albert G. Rooks, P-H 1953 T.C. Mem. Dec. I53036; A. D. Clark, P-H 1942 T.C. Mem. Dec. If 42433 ; cf. T. J. Coffey, Jr., 14 T.C. 1410 (1950). 
a valid business purpose. ${ }^{96}$ However, the courts might accept the argument in the latter case that the distributions to the sellers should be given capital treatment because the transaction is an integrated one, the ultimate effect of which is to terminate their interests in the corporation. ${ }^{97}$

With respect to the buyers, the approach under both the 1939 and 1954 Codes revolves around the question of whether the distributions to $A$ and $B$ should be considered as ordinary income to $C$ and $D$. Under the old Code, if the obligation to acquire the sellers' stock was solely that of the corporation, the redemption of that stock was not considered as a dividend to the buyers. ${ }^{98}$ Thus in Ray Edenfield, ${ }^{99}$ the corporation redeemed stock from the sellers and issued second mortgage bonds in payment thereof. The subsequent payments on these bonds by the corporation were held not to be taxable to the purchasers since the bonds were the obligation of the corporation and in no sense that of the buyers. A similar result was reached even where the buyers themselves acquired the stock but were able to show that they were acting merely as the agents of the corporation and that the obligation to acquire the stock was actually that of the corporation..$^{100}$ If, on the other hand, the buyers were personally obligated by the purchase agreement to obtain the sellers' interests, a redemption of the sellers' stock by the corporation was considered as a dividend distribution to the buyers, on the theory that the corporation discharged the debt owed by the buyers to the sellers. ${ }^{101}$ This distinction based on whether the acquisition of stock is the obligation of the buyers or of the corporation can be continued by the courts in interpreting the new Code because there is nothing in the statutory scheme which would eliminate it.

The effect of these doctrines which were developed under prior law and which would seem to be perpetuated under the 1954 Code is to permit the corporation's surplus to be used to accomplish the purchase of the corporation with no tax on the buyers and with capital treatment to the sellers. One justification for this is that the same result could be achieved through a purchase and liquidation. $C$ and $D$ could purchase $A$ 's and $B$ 's stock for cash and notes, using the stock acquired as the security for the notes. $C$ and $D$ then could completely liquidate the corporation and utilize the proceeds to pay off the notes. In such a situation $A$ and $B$ would be given capital treatment and presumably there would be no tax on $C$ and $D$, since the purchase price of the stock would reflect the total value of the cor-

96. See text following note 145 infra.

97. Compare the approach taken by the district court in Zenz v. Quinlivan, 106 F. Supp. 57, 61 (N.D. Ohio 1952), rev'd, 213 F.2d 914 (6th Cir. 1954).

98. Ray Edenfield, 19 T.C. 13 (1952), acq., 1953-1 Cum Bul.. 4; Max Viault, 36 B.T.A. 430 (1937).

99. 19 T.C. 13 (1952), acq., 1953-1 CuM. Bull. 4.

100. Fox v. Harrison, 145 F.2d 521 (7th Cir. 1944). But cf. Mendle Silverman, P-H 1954 T.C. Mem. Dec. If 54168; Frank P. Holloway, P-H 1951 T.C. Mem. Dec. If 51359, aff'd, 203 F.2d 566 (6th Cir. 1953).

101. Wall v. United States, 164 F.2d 462 (4th Cir. 1947); Mendle Silverman, supra note 100; Frank P. Holloway, supra note 100. See Rev. Rul. 458, 1954 INT. Rev. Bull. No. 42, at 15 . 
poration's assets. ${ }^{102}$ However, this plan would require that the business be operated in the future as a partnership..$^{103}$ If $C$ and $D$ wished to continue operation in the corporate form, they could organize Corporation $Y$, contribute the amount of money to it that they intend to pay for the operating assets of Corporation $X$, and receive in return Corporation $Y$ 's stock. Corporation $X$ then could adopt a plan of complete liquidation and sell its operating assets to Corporation $Y$ for the cash contributed by $C$ and $D .104$ If Corporation $X$ completely liquidated within one year following the adoption of the plan of liquidation, ${ }^{105}$ it could distribute all of its remaining assets, including those attributable to its earnings and profits, to $A$ and $B$ with no tax on $C$ and $D$ or on the corporation and with $A$ and $B$ receiving capital gain or loss treatment. ${ }^{106}$ In both the case of the redemption and the case of the purchase and liquidation the basic reason for this favorable tax treatment would seem to be that the sellers are terminating their interests in the corporation and the buyers own a corporation which does not have all of the assets it possessed prior to the sale.

\section{Distributions Under Section 346}

The dividend equivalence provision in Section 346 (a) can best be interpreted by first examining the two-business test contained in Section 346 (b), because the specific test is prescribed by statute to be one example of a distribution which is within the general provision. ${ }^{107}$

Two Businesses Held for Five Years.-Although the two-business partial liquidation described in Section 346(b) is more definite than the general dividend equivalence test, it does raise certain problems, the primary one revolving around the question of what constitutes two businesses. Neither the Statute nor the Proposed Regulations ${ }^{108}$ is of much assistance in solving this problem. While one requirement is that the two

102. There is also the possibility of the integrated transaction approach of the Kimbell-Dianond case (Kimbell-Diamond Milling Co. v. Commissioner, 187 F.2d 718 (5th Cir.), cert. denied, 324 U.S. 827 (1951)) being applied to this situation and the assets received as liquidating distribution would take the same basis as the stock surrendered. See Cohen, Gelberg, Surrey, Tarleau \& Warren, Corporate Liquidations Under the Internal Revemue Code of 1954, 55 CoL. L. Rev. 37, 43 n.32 (1955).

103. A complete liquidation followed by a reincorporation of the operating assets presents the possibility that the transaction would be treated as a reorganization with a distribution of "boot" to the shareholders. See Survaunt v. Commissioner, 162 F.2d 753 (8th Cir. 1947). BuLl. 4.

104. See Distributors Finance Corp., 20 T.C. 768 (1953), acq., 1954-1 CuM. 45.

105. See INt. REv. Code of 1954, §337. See Cohen, et al., supra note 102, at

106. However, it should be noted that in these situations the basis of the operating assets would be changed while in the redemption case it would remain the same. See INT. REV. CODE of 1954, \$334. Where the new basis would be lower than the old adjusted basis, the purchase of the corporation by a plan involving a complete liquidation would not be desirable for the buyers.

107. INT. REV. CODE OF 1954, \$346(a) (2), (b).

108. The Proposed Regulations under $\$ 346$ refer to the regulations under $\$ 355$. U.S. Treas. Proposed Reg. \$1.346-1 (c) (2), 19 FED. REG. 8268 (1954). However, the latter are of little assistance. See id. §1.355-4(b) (3), 19 Fed. REG. 8279 (1954). 
trades or businesses be actively conducted, ${ }^{109}$ there is no indication of the point at which two activities or departments of the same corporation will be considered sufficiently separate to come within the statutory requirement.

Assume that Corporation $X$ was formed in 1893 to wholesale groceries and dry goods; in 1912 it began to manufacture dry goods; in 1919 it undertook certain warehousing operations; in 1926 it started to conduct a cannery; and in 1932 it began operating some retail outlets. Each of these operations had different management personnel and each was treated separately for bookkeeping purposes. By 1955 the corporation had sustained losses in the manufacturing and canning departments; as a result they were liquidated and the proceeds were distributed to the shareholders in exchange for some of their stock. ${ }^{110}$ These two operations, which primarily involve the production of goods, would seem to be sufficiently separate from the remainder of the corporation's activities to qualify as trades or businesses within the meaning of Section $346(\mathrm{~b})$. In addition, the assets of the liquidated operations are distinguishable from the assets used in the corporation's other branches.

A case which would be more difficult to fit within Section $346(\mathrm{~b})$ is one in which a corporation manufactures men's overalls and women's blouses. The two activities require different machines and separate inventory, but they are conducted in the same building, operated under the same management personnel, and are treated together for bookkeeping purposes. The corporation pursuant to a plan ceases to manufacture blouses, disposes of the inventory and machinery connected with this operation, and distributes the proceeds to its shareholders in return for some of their stock. As in the case discussed above, the assets which were sold are distinguishable from the remaining assets of the business. On the other hand, the fact that the two activities were treated as one business for management and bookkeeping purposes raises some doubt as to whether the distribution would come within the specific example. The House version of this section contained a provision which required that each business have its own books and personnel, ${ }^{111}$ and the Senate Committee Report does not indicate the reason for eliminating this provision. It might be that the Senate considered these factors to be insignificant, but the more likely inference is that they were deleted as a result of the general policy of the Senate to provide greater flexibility. The percentage of the business which the production of the blouses represented could also have a bearing on the result. Thus, if it constituted 90 percent of the business, the change undertaken by the corporation is considerably greater than if it represented less than 50 percent of the business. The conclusion is that it is very questionable whether this type of situation involves the liquidation of a

109. See SEN. REP. 262. See text at and following note 135 infra.

110. See Heber Scowcroft Investment Co., P-H 1945 T.C. Mem. Dec. $\{45235$.

111. The House Bill specified that books and records for the two businesses have been kept separately, that they have been operated separately, and that $90 \%$ of the gross income have been attributable to other than personal holding company income. H.R. 8300, 83d Cong., 2d Sess., \$336(a) (2)-(A),(B),(C) (1954). 
separate trade or business, or whether it merely involves the "dropping of an old product" or "changing the capacity" of the business. ${ }^{112}$ This diffculty suggests that in such a situation the taxpayer probably will argue that the distribution to him comes within both the two-business test and the general dividend equivalence standard.

The requirement that the two businesses have been actively conducted for five years prior to the distribution would seem to be a codification of a business purpose test. Primarily, this provision prevents shareholders from receiving favorable tax treatment if the corporation acquires a trade or business and immediately liquidates it. Although this could be accomplished under Section 346 (b) by acquiring, through a tax-free reorganization, a business which had been actively conducted for five years, the resulting dilution of the shareholders' equity interest in the corporation probably would be sufficiently great to render the scheme unattractive as a means of withdrawing earnings and profits from the corporation. Apparently, the supposition behind the active-conduct rule is that a corporation would not acquire a business and operate it for five years unless there were good business reasons for doing so.

It is at the point of the specific example of Section 346 that the greatest correlation is found with the reorganization provisions. ${ }^{113}$ Thus, in any case under Section 346(b) where a partial liquidation could be effected it would seem to be possible to continue the separate business as a different corporation by the application of Section 355. Similar problems arise in each case as to what constitutes a separate trade or business. The primary distinctions between the two provisions result from the different purpose of Section 355, which is to "limit [its] application . . . to those cases in which the distribution of stock of the controlled corporation effects only a readjustment of continuing interests in property under modified corporate form." 114 Accordingly, Section 355 requires that both businesses be actively conducted following the division, ${ }^{115}$ and it contains provisions for adjusting the basis of stock and assets. The stock distributed to the shareholder ${ }^{116}$ and the property distributed to the new corporation ${ }^{117}$ both take a transferred basis. On the other hand, in the case of a partial liquidation, the assets distributed to the shareholders would take a new basis.118 Of course, eventually the same result can be achieved un-

112. U.S. Treas. Proposed Reg. \$1.355-4(b) (3), 19 FED. Rec. 8272 (1954). See note 108 supra. A similar question is presented if a corporation having many different retail outlets liquidates one of them. Cf. Rev. Rui. 270, 1953-2 Cum. BuLL. 35.

113. Compare INT. Rev. CoDE of 1954, §346(b), with id. §355(b) (2). See Cohen, Silverman, Surrey, Tarleau \& Warren, The Internal Revenue Code of 1954: Corporate Distributions, Organizations, and Reorganizations, 68 HARv. L. REv. 393, 426-32 (1955).

114. Rev. Rul. 103, 1955 Int. Rev. Buli. No. 9, at 7-8.

115. INT. Rev. CoDE of $1954, \S 355$ (b) (1).

116. $I d$. $\$ \$ 358(\mathrm{a})(1),(\mathrm{c})$.

117. Id. $\$ 362(\mathrm{~b})$.

118. Id. $\$ 334$ (a). A liquidation followed by a reincorporation in an effort to obtain a stepped-up basis would probably be considered a reorganization. See note 103 supra. 
der Section 355 as is reached under Section 346, since, at a future date, one of the corporations can be liquidated and the assets distributed at capital gains rates.

Two Businesses Not Held for-Five Years.-An example of a situation where there are two businesses not operated for five years is $L$. M. Lockhart ${ }^{119}$ in which a corporation organized by the taxpayer in 1939 conducted oil drilling and production operations. Taxpayer was the sole shareholder, and in 1943 he decided to separate the oil drilling from the production operations of the business. Accordingly, the corporation redeemed stock and distributed the assets connected with the production facilities, and the taxpayer assumed the liabilities incident to these facilities. The Tax Court held that the distribution was not equivalent to a dividend. The court reasoned that the desirability of divorcing the production operations from the liabilities connected with the drilling operations was a sufficiently valid business purpose to outweigh the evidence that the taxpayer was in need of cash.

In this case the expiration of the five-year period was so close at hand that it is possible that the taxpayer might wait before undertaking the separation. However, if he wanted to split the corporation immediately, the question arises as to whether the distribution would come within the dividend equivalence test. Under the new Code, the period for which the distributed business had been operated would seem to assume great importance to offset the possibility of distributing excess surplus at a favorable tax rate by purchasing a business and liquidating it shortly thereafter. If the fiveyear requirement of the specific test is considered to be a codification of a business purpose rule, then, as other business reasons for making a distribution are shown to be stronger, the time element would seem to be reduced concomitantly in importance. In determining whether a valid business purpose exists, significant factors probably would be the reason for commencing the operation of the separate business, ${ }^{120}$ the success or failure of the operation, and the basic reasons behind the decision to liquidate.

General Business Contraction.-Corporation $X$ was organized in 1893 to engage in the manufacture of paper products. In 1921 it was felt that the capital stock of the corporation should be increased to keep it in line with expanding business, since the gross sales and accounts receivables had increased substantially. Therefore, a common stock dividend with respect to common stock was issued, and the corporation transferred a corresponding amount of surplus to its capital stock account. However, after 1930 the business decreased considerably because of changed economic conditions, and in 1938 some of the principal shareholders discussed the pos-

119. 8 T.C. 436 (1947).

120. The situation here is not unlike that posed in cases of redemption of stock previously issued as a dividend where the courts determined that if both the issuance and subsequent redemption were for valid business reasons the transaction was not equivalent to the distribution of a taxable dividend. See text at note 122 and note 122 infra. 
sibility of liquidating the corporation. In 1941 it was decided that the capital of the corporation was in excess of its needs and to that extent unprofitable; therefore, pursuant to a plan, two-fifths of the stock of each shareholder was redeemed for cash. ${ }^{121}$

Decisions under the 1939 Code held that where a stock dividend and a subsequent stock redemption were undertaken for valid business reasons the distribution would qualify for capital gains treatment. ${ }^{122}$ Under the new Code the primary question is whether this case involves a contraction which comes within the general dividend equivalence standard of Section 346.

The Senate Report states that this general test in Section 346 includes situations "involving the contraction of a corporate business" 123 and cites as an example the case of Joseph W. Imler. ${ }^{124}$ The Imler case, as interpreted by the Senate, ${ }^{125}$ involves an involuntary contraction of the corporation's business resulting from a fire which destroyed the upper two floors of a building owned by the corporation. Therefore, it is apparent that in Imler there was a clearly identifiable event which showed a definite contraction of the business and which led to the reduction in the corporation's capital. The court said that under the circumstances this constituted a valid business purpose for making the distribution. ${ }^{128}$ If the significance of the Imler case is that there must be a valid business purpose for the diminution of the corporate activities and the consequent reduction in capital, it would seem that the hypothetical example would qualify under Section 346. While there is no identifiable event in this situation such as that in Imler, the corporation could show that there has been a decided reduction in its sales and accounts receivable over the ten-year period prior to the distribution, and under Section 346 this would seem to be a sufficiently valid reason for redeeming part of its capital stock. ${ }^{127}$ This case is essentially one in which the effect on the corporation's assets was from an outside source, the changed economic conditions. A more difficult problem is presented by the situation in which the contraction is basically voluntary on the part of the corporation. The Senate Report states that "[v]oluntary bona fide contraction of the corporate business may . . .

121. See Samuel A. Upham, 4 T.C. 1120 (1945), acq., 1945 Cuns. Burl. 7.

122. See, e.g., Samuel A. Upham, supra note 121; John P. Elton, 47 B.T.A. 111 (1942), acq., 1942-2 CuM. BuLt. 6; Henry B. Babson, 27 B.T.A. 859 (1933), aff'd, 70 F.2d 304 (7th Cir.), cert. denied, 293 U.S. 571 (1934). But cf. Dunton v. Clauson, 67 F. Supp. 839 (D. Me. 1946).

123. See Sen. Rep. 49, 262.

124. 11 T.C. 836 (1948), acq., 1949-1 Cum. Bull. 2. See Sen. Rep. 49, 262.

125. The Imler case can be interpreted as a case involving the cessation of one of two businesses. Joseph W. Imler, 11 T.C. 836, 840-41 (1948) acq., 1949-1 CuM. BuLL. 2. However, the Senate Report and the Proposed Regulations seem to consider this case as a general business contraction, without reference to the two-business element. See SEN. REP. 262; U.S. Treas. Proposed Reg. § 1.346-1(a), 19 FED. REG. 8267 (1954).

126. Joseph W. Imler, supra note 125 , at 841 .

127. Cf. Samuel A. Upham, 4 T.C. 1120, 1127-28 (1945), acq., 1945 Cum. Bull. 7. 
qualify to the same extent as under existing law," ${ }^{128}$ but that a distribution from a "reserve for expansion is not a partial liquidation." 129 This suggests that the Imler situation constitutes one extreme and a distribution from a reserve for expansion the other, with bona fide voluntary contractions lying somewhere between the two: However, it is difficult to determine which situations fall within this middle area. Suppose a corporation has been operating a department store, sells the store, and proceeds to open a small shop specializing in ladies' apparel. If the new shop requires a considerably smaller amount of capital to operate than did the department store and the corporation redeems some of its stock, it would seem that the distribution would come within the concept of a voluntary bona fide contraction under Section 346. On the other hand, if the operation of the apparel shop necessitates only slightly less capital than was required by the department store, a distribution of excess surplus which had been built up prior to the sale of the old store probably would not qualify under Section 346 since it would not have resulted from the contraction. ${ }^{130}$

A transaction probably will have greater difficulty coming within Section 346 as it approaches a distribution from a reserve for expansion. Assume that a corporation has a substantial surplus, and, in contemplation of expanding its business, reduces the surplus by issuing a stock dividend to its shareholders and on its books transfers the amount from the surplus account to the capital account. However, eight years later it becomes apparent that the expansion program is no longer feasible because of changed business conditions and new developments in other fields affecting the corporation's sales. Consequently, the corporation disposes of the few assets which it had acquired in connection with the program, and redeems the stock which previously had been issued as a dividend.131 Under the prior law, it is possible that the transaction would have been treated within Section $115(c)$ as a valid partial liquidation. ${ }^{132}$ However, had there been

128. SEN. REP. 49. The Report would seem to draw a distinction between voluntary and involuntary contractions, since the phrase here quoted follows the discussion of the Imler case. However, compare the discussion on page 262 of the Report: "It is intended that a genuine contraction of the corporate business as under present law will result in partial liquidation. . . However, a distribution of a reserve for expansion is not a partial liquidation."

129. Id. at 262.

130. See Estate of Charles D. Chandler, 22 T.C. 1158 (1954). In this case the fixtures and inventory of both the new and old stores were almost the same, and the Tax Court viewed the excess cash which was distributed as not created by the change in business activity but instead the distribution of what was previously an unnecessarily large surplus. Id. at 1165 . This treatment suggests the possibility that a distribution which the court views as carrying along excess surplus would be split, part qualifying under $\$ 346$ and the remainder having to qualify under $\S 302$ or be subject to taxation under $\S 301$. If the distribution is pro rata it would probably not qualify under $\S 302$ and hence would be subject to taxation under $\S 301$.

See U.S. Treas. Proposed Reg. \$1.302-1, 19 FED. REg. 8239 (1954).

131. See T. Pierre Champion, 27 B.T.A. 1312 (1933), aff'd, 78 F.2d 513 (6th Cir. 1935).

132. T. Pierre Champion, supra note 131; Commissioner v. Babson, 70 F.2d 304 (7th Cir.), cert. denied, 293 U.S. 571 (1934). But cf., E. M. Peet, 43 B.T.A. 852 (1941). 
no stock dividend, but instead an allocation of part of the surplus as a reserve for expansion, the distribution would have been taxed as a dividend under Section $115(\mathrm{~g}) .{ }^{133}$ Although the hypothetical example is very similar to a distribution from a reserve for expansion, it is possible that, if there is sufficient evidence of a valid business purpose, the courts, in interpreting the new Code, might continue to apply those cases developed under prior law which taxed the distribution as a capital transaction.

Investment of Surplus in Liquid Assets.-The $X$ Corporation, which manufactures men's suits, for a number of years has invested a substantial percentage of its profits in various securities, instead of distributing them to its shareholders. The corporation has collected distributions incident to these securities and has purchased and sold them, as in the management of any investment portfolio. Because it is unwilling to have this fund subject to the risks of the manufacturing operation, the corporation, pursuant to a plan, redeems some of its outstanding shares and distributes to its shareholders the securities, or the amounts realized from their sale. ${ }^{134}$ This situation presents two questions under Section 346: first, whether the investment activity, particularly if it was conducted for five years, can be considered a separate business, and second, whether the distribution resulted from a bona fide corporate contraction.

In its definition of a separate business, the House Bill specifically excluded a business whose gross income includes more than 10 percent of personal holding company income. ${ }^{\mathbf{1 3 5}}$ According to the House Report, the purpose of this provision was "to insure that the terminated business (and at least one of the businesses remaining) be an operating business." 136 The Senate deleted this requirement, but it gave no indication of the reason for doing so. An inference can be drawn that the intention was to permit the distribution of an investment fund by a manufacturing corporation to qualify under Section $346(\mathrm{~b})$. On the other hand, it can be maintained that the provision was omitted in order to accord with the Senate's policy of providing greater flexibility and that other requirements of Section 346 (b) may govern the situation. One reason why the Senate inserted the requirement that the terminated and remaining businesses be "actively conducted" ${ }^{137}$ may have been to assert the same idea which the House expressed by referring to "operating businesses," and for this reason it can be argued that the type of situation being discussed here does not come within Section 346(b). This contention finds support in the case of Edward L. Kraus, Jr., Trust ${ }^{138}$ which was decided under the 1939 Code. In this case a corporation was engaged in the manufacture of slates and also

133. McGuire v. Commissioner, 84 F.2d 431 (7th Cir. 1936).

134. See Fyman v. Helvering, 71 F.2d 342 (D.C. Cir.), cert. denied, 293 U.S.

570 (1934) ; Edward L. Kraus, Jr., Trust, 6 T.C. 105 (1946).

135. H.R. 8300, 83d Cong., 2d Sess. \$336(a) (2) (C) (1954).

136. H.R. ReP. No. 1337, 83d Cong., 2d Sess. A112 (1954).

137. INT. REv. CODE of 1954, §346(b) (1),(2).

138. 6 T.C. 105 (1946). 
had invested a large amount of surplus in securities; the securities were liquidated and the amounts realized were distributed to the shareholders. The taxpayer argued that the corporation had conducted two businessesa slate business and an investment business-and that the termination of the latter constituted a partial liquidation. ${ }^{139}$ The Tax Court concluded that the securities represented the investment of accumulated profits and that their liquidation merely served to return these profits to the corporation rather than to liquidate a separate "business." 140

It also would seem that the reasoning of the Kraus decision would weigh against the contention that the hypothetical situation qualifies as a bona fide corporate contraction. In addition, this situation is similar to the distribution of a reserve for expansion, since in both cases the shareholders are receiving surplus which has never been dedicated to the manufacturing operation. Moreover, ceasing to conduct the investment activity will cause no reduction in the amount of capital needed to manufacture the suits. In this respect, the hypothetical is similar to the one discussed above in the "general contraction" section, 141 and the conclusion reached there was that the distribution would not qualify as a bona fide contraction.

This determination is substantiated further when Section 355 is considered. This provision is phrased in terms similar to Section 346 with respect to active conduct of a trade or business, ${ }^{142}$ and the Senate Report clearly states that a separation of investment activities of a business from its manufacturing operations does not qualify as a valid corporate division. 143 Because Sections 346 and 355 are closely related and because it is desirable that the same result be reached regardless of which form the transaction takes, the argument can be made that the hypothetical example should not qualify under the former section.

It would seem that when amounts attributable to surplus are used to purchase another operating business for a sound business reason they may, at some later date, be distributed and taxed as capital gains or losses, but when they are invested in liquid assets their subsequent distribution will be taxed as ordinary income. This is a distinction of doubtful validity, since its only justification may rest on a desire to allow the separate business to be distributed in kind and operation continued on the partnership or sole proprietorship level without the tax law being too strong a deterrent. However, this justification breaks down because there is no requirement that the separate business be distributed in kind; instead, it may be liquidated and the amounts received distributed. In this situation all that has happened is that surplus funds previously invested in a separate business have been changed into a readily distributable form, which does not seem to be substantially different from the case where the surplus is invested in

139. Id. at $119-20$.

140. Id. at 120-21.

141. See text at and preceding note 130 stpra.

142. Compare Int. Rev. Code of 1954, $\$ 355$ (b) (2) (A), with Id. $\$ 346(\mathrm{~b})$ (1).

143. SEN. ReP. 51. 
liquid assets. Furthermore, even if the separate business is distributed in kind and operated as a partnership or sole proprietorship, it can eventually be disposed of and the individual can realize the amounts received as capital gain or loss. Therefore the distinction which the Code seems to draw between the investment of surplus in a separate business and in liquid assets can be questioned.

\section{Overlapping Distributions}

Cancellation of Indebtedness.-Assume that $A$ is the sole shareholder of the $X$ Corporation. $A$ has maintained a drawing account with the corporation, using the money withdrawn for his personal needs, and, at various times, he has paid back some of the money or has credited his account on the corporation's books with amounts owed to him as salary. However, a balance has accumulated in favor of the corporation. $X$ Corporation is dependent on a great deal of credit in its operations, and, therefore, it is essential that it maintain a high credit rating and obtain a low interest rate. A change in business conditions has placed the corporation in a bad financial position, and its regular sources of credit require that $A^{\prime} s$ indebtedness be cancelled before they will take any more of its commercial paper at a favorable rate of interest. As a result, $A$ has the corporation redeem some of his stock in return for the cancellation of the debt. ${ }^{144}$

The distinction drawn in the cases decided under the 1939 Code seems to be that, when there was strong pressure to cancel the indebtedness from a source outside the corporation, the redemption was not treated as a dividend on the theory that there was a valid business purpose for undertaking the transaction; lacking the outside pressure, there was an insufficient business purpose and the opposite result was reached. ${ }^{145}$ Under the 1954 Code this hypothetical case might fit within either Section 302 or Section 346 or it might fall outside the scope of both of these provisions. Since $A$ is the sole shareholder, the redemption of some of his stock has no effect on the shareholder level because his equity interest in Corporation $X$ remains the same as before the distribution. However, an argument can be made that a pro rata redemption such as this one will come within the dividend equivalence standard of Section 302 . The

144. See J. Natwick, 36 B.T.A. 866 (1937); Isaac C. Eberly, P-H 1951 T.C. Mem. Dec. $\{51351$; A.C. Monk, P-H 1947 T.C. Mem. Dec. II 47247 ; William W. Wood, 3d, P-H 1943 T.C. Mem. Dec. $\llbracket 43488$. Doubt has been expressed whether reduction of a shareholder's indebtedness to the corporation by redeeming stock constitutes an improvement in the corporation's financial position from the standpoint of the creditors. See L. B. Hirsch, 42 B.T.A. 566, 571-72 (1940), aff'd, 124 F.2d 24 (9th Cir. 1941). However, it seems to be considered sufficient. See Isaac C. Eberly, supra at pp. 1161-63.

145. See Bona Allen, Jr., 41 B.T.A. 206, 210-11 (1940). Compare Isaac C. Eberly, supra note 144, writh J. Natwick, supra note 144. In Ada Murphy McFarlane, P-H 1954 T.C. Mem. Dec. If 54144, a distribution was held not equivalent to a dividend because pressure from the taxpayer's son, a shareholder in the corporation, to cancel indebtedness by a stock redemption was considered sufficient to show a business purpose. 
Senate Report states that the test to be utilized in interpreting the dividend equivalence test is in general the one employed under the old Section $115(\mathrm{~g})$ and that in applying this test the inquiry is to be devoted solely to the question of whether or not the transaction may be characterized as a sale of stock by the shareholder to the corporation. ${ }^{148}$ Therefore, the hypothetical example could come within the dividend equivalence standard of Section 302 by applying the rationale of the cases decided under the prior law and by saying that the existence of a valid business purpose means that there has been a "sale" to the corporation. The primary difficulty with this approach is that it applies a factor which does not have an effect on the shareholder level and thus would result in a broadening of Section 302 which does not find substantial support in the Senate Report ${ }^{147}$ or the Proposed Regulations. ${ }^{148}$

It is also questionable whether the distribution will come within the scope of Section 346. Qualification for capital treatment depends on whether the dividend equivalence test of this section encompasses something other than the concept of corporate contraction. The Senate Report states that the definition of partial liquidation "would include" 149 and "involves primarily, . . . the concept of 'corporate contraction' as developed under existing law," ${ }^{150}$ and this does not exclude the possibility of other transactions coming within the dividend equivalence test. ${ }^{151}$ The equivocal language of the Senate Report may result in the courts' applying the prior case law that the existence of a valid business purpose means that the distribution is not essentially equivalent to a dividend. On the other hand, the derivation of Section 346 may encourage courts to limit it to corporate contractions, since the antecedent provision of the House Bill was expressly restricted to this type of situation. ${ }^{152}$ Although the Senate inserted the dividend equivalence test in Section 346 in order to provide flexibility, the intention may have been to restrict the application of this section to corporate contractions and to permit elasticity only within this limited area.

One reason for not allowing this hypothetical example to qualify under either Section 302 or Section 346 is that a distribution in a closely analogous case would be treated as a dividend. Suppose that the $X$ Corporation redeems some of the stock of $A$, its sole shareholder, because $A$

146. SEN. REP. 234.

147. "Those distributions which may have capital-gain characteristics because they are not made pro rata among the various shareholders would be subjected, at the shareholder level, to the separate tests described in [Section 302]...." Id. at 49 .

148. U.S. Treas. Proposed Reg. §1-302-2(b), 19 Fed. REG. 8239 (1954).

149. SEN. REP. 49 (italics added).

150. Id. at 262 (italics added).

151. This is true also of the Proposed Regulations. See U.S. Treas. Proposed Reg. \$1.346-1(a), 19 FED. REG. 8267 (1954).

152. H.R. 8300, 83d Cong., 2d Sess. $\$ 336$ (a) (1954). H.R. Rep. No. 1337, 83d Cong., $2 \mathrm{~d}$ Sess. 35 (1954). 
needs a considerable sum of money to meet his personal expenses. ${ }^{153}$ Under the 1939 Code the transaction was treated as a dividend because of the absence of a valid business purpose, and the same result would be reached under the 1954 Code. The only distinction between such a case and the indebtedness cancellation situation is that in viewing the latter solely at the time of redemption it can be said that the pressure of the creditors provides a valid business purpose. However, there is essentially no difference between these two situations; in each, the redemption was necessitated by the fact that the shareholder received money from the corporation for his personal needs.

In order to provide uniform tax treatment, the result reached under Section 346 should be the same as that reached if the transaction takes the form of a reorganization. Assume that the $X$ Corporation, for the same reason as in the basic hypothetical example in this section, recapitalizes by issuing new common stock and cancelling $A$ 's indebtedness in return for $A$ 's old stock. The cancellation would be treated as "boot" and therefore subject to taxation under Section 356. ${ }^{154}$ The problem then would be whether the transaction had "the effect of the distribution of a dividend." 155 However, the resolution of this question is no more definite than the one involved in interpreting the dividend equivalence test as contained in Sections 302 and 346..$^{150}$

Acquisition of Stock for Resale to Employees.-Assume a case in which the stock of the $X$ Corporation is held by $A$ and $B$, who are unrelated individuals. The corporation redeems some of its stock from the two shareholders in equal amounts and resells it to certain key employees in order to give them a proprietary interest in the business. ${ }^{157}$

The basic question involved here is the same as that involved in the case of indebtedness cancellation, namely, whether Section 302 includes within its scope anything other than non-pro rata redemptions and whether Section 346 encompasses anything other than corporate contractions. ${ }^{158}$ The primary difference with respect to Section 302 is that an argument can be made that the employee case qualifies under the dividend equivalence test on the basis that the interests of $A$ and $B$ have been changed, since

153. See Frenette v. Broderick, 5 CCH 1954 Stand. Fed. Tax ReP. (54-2 U.S.T.C.) $\pi 9458$ (D.C. Kan. May 19, 1954); Raymond F. Koepke, P-H 1954 T.C. Mem. Dec. $\int 54273$, appeal filed, No. 46582, 6th Cir., Jan. 10, 1955.

154. INT. REv. CODE OF 1954, §356(a) (1).

155. Id. $\S 356(\mathrm{a})(2)$. See John L. Hawkinson, 23 T.C. No. 117 (Feb. 28, 1955); R. D. Walker, 34 B.T.A. 983 (1936), acq., XV-2 CUM. BUL. 25 (1936).

156. It may be possible that a distribution of "boot" is more likely to be treated as having the effect of a dividend than is a distribution in redemption of stock because of the influence of Commissioner v. Estate of Bedford, 325 U.S. 283 (1945). See John L. Hawkinson, supra note 155. However the determination in each case should be made in a manner similar to that undertaken in determining qualification within the redemption provisions. See Wittenstein, Boot Distributions and Section 112(c)(2): A Re-Examination, 8 TAX L. REv. 63 (1952).

157. See Commissioner v. Snite, 177 F.2d 819 (7th Cir. 1949).

158. See text following note 145 sitpra. 
the resale to the employees dilutes the shareholders' equity interests in the corporation. However, this differs from a non-pro rata redemption in that here the interests change not by reason of the redemption but because of the subsequent sale of stock. Nevertheless, this change of interest coupled with the showing that the redemption was undertaken primarily to benefit the corporation may be sufficient to bring this type of case within the dividend equivalence standard of Section 302. If the dividend equivalence test of Section 346 includes distributions other than those involving corporate contractions, it may be easier for the taxpayer to receive capital treatment in this case than in the cancellation of indebtedness situation. In the employee hypothetical the reason for the redemption, to have stock available for resale to key personnel, is to benefit the corporation, while in the case of indebtedness cancellation the reason for the original creation of the debt was solely to benefit the shareholder.

Redemption of Preferred Stock. ${ }^{158}$-Suppose that the $X$ Corporation has authorized and issued 30 shares of voting common stock of which $A$ holds 20 shares and $B$ and $C$, the other two shareholders, each own 5 shares. At one time, the corporation was in financial difficulties and it became necessary for the three shareholders to lend money to the corporation, which they did in equal amounts. However, other creditors demanded that the claims of the shareholder-lenders be subordinate to their claims, and thus preferred stock was issued instead of bonds or notes. ${ }^{160}$ $A, B$ and $C$ each received 10 shares of the preferred stock, which is nonvoting but is cumulative as to dividends and contains a provision for voting rights if default is made in the payment of dividends. After three years the $X$ Corporation's finances improve and it redeems 5 shares of the preferred stock from each of the three shareholders. ${ }^{161}$

Under the 1939 Code this redemption probably would not have been taxed as a dividend on the theory that the transaction was similar to the payment of a debt owed by the corporation to its shareholders. ${ }^{162}$ Consideration of this problem under the 1954 Code raises questions of whether

159. Problems relating to this aspect of the new law are also considered in Bittker, Stock Dividends, Distributions in Kind, Redemptions, and Liquidations, Under the 1954 Code, 1955 So. Calif. Tax Insr. 349, 385-88.

160. See G. E. Nicholson, 17 T.C. 1399, 1407 (1952), acq., 1953-1 Cum. Bull. 5. If debentures would be issued subordinate to other creditors and the amount of debentures was out of proportion to the capital stock, problems of "thin capitalization" might result. See Fuchs, Thin Incorporations-Debt or Stock?, 5 Ax. U. TAX INST. 141 (1953).

161. G. E. Nicholson, supra note 160; Marjorie K. Hatch, P-H 1954 T.C. Mem. Dec. $\{54114$.

162. See note 161 supra. Had the preferred stock been issued for cash at the time of formation of the corporation and redeemed a few years later, the redemption would have been treated as equivalent to a dividend under the 1939 Code on the ground that the shareholders were using earnings and profits to recoup their investment as soon as possible. Stein v. United States, $104 \mathrm{Ct}$. C1. 446, $62 \mathrm{~F}$. Supp. 568 (1945) ; Samuel L. Cantor, P-H 1953 T.C. Mem. Dec. I 53182. But cf. George A. Lembcke, 33 B.T.A. 700 (1935), nonacq., XV-I CUM. BuLL. 37 (1936). In Stanley Sagner, P-H 1953 T.C. Mem. Dec. If 53378, a redemption of preferred stock was allowed at capital gains rates shortly after formation of the corporation because of a finding of corporate contraction. 
it will qualify for capital treatment and, if so, within which provision. If only the preferred stock is considered, the redemption is pro rata and each of the shareholders will have a difficult time in bringing the distribution to him within the dividend equivalence standard of Section 302 . However, if the preferred and common stock are considered together, an argument can be made that the distributions to $B$ and $C$ should qualify under this standard. ${ }^{163}$ Under this approach, there is a change of interests on the shareholder level, because before the redemption $A$ owned 50 percent of all of the corporation's stock and $B$ and $C$ each owned 25 percent while after the redemption $A$ owns 55.5 percent and $B$ and $C$ each own 22.2 percent. The effect of this is that the preferred stock is now less of an impediment on $A^{\prime} s$ common stock. This will be expressed in the future by the opportunity for a greater percentage of the corporate profits coming to him through common stock dividends and also by the lessening of the danger of losing control of the corporation through default on the payment of dividends on the preferred stock. $B$ 's and $C$ 's interests in the profits of the corporation will decrease concomitantly. Whether this represents a sufficient change in interest to bring the distributions to $B$ and $C$ within the dividend equivalence test of Section 302 cannot be ascertained without the development of judicial and administrative interpretations. However, taking the approach suggested here, the distribution to $A$ should not qualify for capital treatment since the redemption has increased his interest in the corporation.

In addition to this argument based on change of interest, it could be maintained that the courts should apply the decisions under the 1939 Code, which gave capital treatment to cases such as this because of their similarity to the corporation's paying off a loan to its shareholders. The problem with using this approach under the dividend equivalence test of Section 302 is that it is equally applicable to the redemption of $A$ 's stock and thus tends to break down the shareholder-by-shareholder theory of this section. Although this difficulty would be avoided if the prior cases were applied in an attempt to bring the hypothetical within the dividend equivalence test of Section 346, it would present the question of whether this provision is to be expanded to cover a distribution which does not result from the contraction of the corporation's assets.

An attempt by the corporation to reduce its preferred stock in the hypothetical case would seem to meet similar problems if a recapitaliza-

163. Even if the preferred stock and common stock are considered together in this case, the distribution cannot qualify under $\$ 302(\mathrm{~b})(2)$ relating to substantially disproportionate redemptions. Under what circumstances a preferred stock redemption can qualify under this provision is a perplexing problem. While the Senate Report makes a general statement that $\$ 302(\mathrm{~b})(2)$ will apply to the redemption of preferred stock, SEN. REP. 234, the Proposed Regulations take the position that a redemption of preferred stock will qualify only if the preferred stock is redeemed simultaneousiy with a change of interest in common and voting stock which will qualify within the percentage requirements of $\$ 302(\mathrm{~b})(2)(C)$. U.S. Treas. Proposed Reg. $\$ 3.02-3(\mathrm{a}), 19 \mathrm{FED}$. REG. 8240 (1954). This problem is discussed in Cohen, supra note 42 , at 749 . 
tion, rather than a redemption, were undertaken. If the corporation exchanged debentures and common stock for the old preferred and common stock, the transaction would be affected by a new provision of the Code. This section specifies that the receipt of securities in a reorganization, when no securities are surrendered, shall not be considered a tax-free exchange, ${ }^{164}$ but instead is to be treated as "boot." 165 Treating the securities received as "boot" 166 requires a consideration of whether their distribution has the "effect of the distribution of a dividend," 167 and this question is no more definite than the one involving the interpretation of the dividend equivalence test.

Each of the three hypothetical problems which has been considered in this section on overlapping distributions involves a situation which does not fit clearly within either Section 302 or Section 346 . The difficulty in giving any of them capital treatment is that it would result in an extension of the dividend equivalence test in one of these two sections beyond the scope which the Senate Report indicates it is to have. However, when faced with these problems, the courts may accord them capital treatment or they may tax the distributions as dividends under Section 301 because they do not fit precisely within the scheme of the Code. It cannot be predicted which of these alternatives the courts will take, but it is clear that they must recognize the difficulties which arise from the attempt of the new Code to separate distributions in redemption of stock into two distinct categories.

\section{CONCLUSTON}

The two poles in the area of corporate distributions are dividends and complete liquidations. The former is defined to include only earnings and profits of the corporation; the latter encompasses the corporation's capital assets as well as its earnings and profits and is taxed at rates applicable to capital transactions. The sections of the 1954 Code dealing with redemptions of stock and partial liquidations attempt to draw a line between these two extremes with respect to distributions in the "gray area." This delineation is accomplished by classifying transactions as qualifying for capital treatment either because the equity interest of a shareholder in the corporation in relation to the other shareholders has changed or because some significant event has occurred on the corporate level, such as a genuine

164. INT. REv. Code of 1954, §354(a) (2) (B).

165. $I d . \S 356$ (d) (1).

166. Although the Senate considered this new provision as reading into the Code the case of Bazley v. Commissioner, 331 U.S. 737 (1947) (holding that receipt of debentures and common stock for common stock in a recapitalization for which no business purpose was shown was not a tax free exchange), see SEN. REP. 51, 269, it seems that the Bazley case as interpreted has been expanded. Decisions under the old Code interpreted Bazley as not applying to an exchange of debentures for preferred stock under certain circumstances. See Penfield v. Davis, $105 \mathrm{~F}$. Supp. 292 (N.D. Ala 1952), aff'd, 205 F.2d 798 (5th Cir. 1953) ; Daisy Seide, 18 T.C. 502 (1952). The new Code considers the receipt of the securities for preferred stock as "boot" under all circumstances.

167. INT. Rev. CODE of 1954, §356(a) (2). 
contraction. The statutory method of setting forth this scheme is such that it combines a series of specific examples and the general dividend equivalence test drawn from the 1939 Code.

This statutory pattern represents a compromise between the rigidity of ${ }^{\prime}$ the House Bill and the indefiniteness of the old Code, but, unless the specific examples are used merely to point the direction which the general test is to take, it may create more problems than it solves. Furthermore, the efficacy of the line drawn by the new Code and the characterization of transactions depending upon the effect on the shareholder or the corporation are open to serious question. The problems of interpretation, which revolve around the vague dividend equivalence test and the overlapping of the two sections, make it difficult to categorize any given situation. Because the new Code lacks a precise standard and takes some of its language from the 1939 Code, there is a strong possibility that prior cases will be given great weight in future court decisions. Since these cases follow no definite pattern, such an approach would result in the possibility of revenue loss for the Government through judicial sanction of tax avoidance plans, and, at the same time, certainty and uniformity for taxpayers would remain a desired but unreached objective. In interpreting the new Code the courts should abandon prior cases and direct their attention to the economic effect of a particular distribution and to the desirability of having uniform tax treatment between Sections 302 and 346 on the one hand and the reorganization provisions on the other. 